\title{
DNA adducts detected by synchronous fluorescence spectrophotometry in rat liver, kidney, lung and spleen after intraperitoneal administration of benzo[a]pyrene
}

\author{
Wanda Baer-Dubowska, Aleksandra Kulińska, Małgorzata Jarmuż, Damian Brauze ${ }^{1}$ \\ and Jerzy Gnojkowski \\ Karol Marcinkowski's University Medical School, Department of Biochemistry, Grunwaldzka 6, \\ 60-780 Poznań, Poland \\ ${ }^{1}$ Institute of Human Genetics, Polish Academy of Sciences, Strzeszyniska 32, 60-479 Poznań, Poland
}

Benzo[a]pyrene $(\mathrm{BP})^{1}$ is the ubiquitous polycyclic aromatic hydrocarbon implicated in cancer of the skin and lung. Extensive evidence indicates that BP must be metabolically activated in order to exert its mutagenic, cell transforming and tumorogenic or carcinogenic effects (reviewed in [1]). Following in vivo treatment the major BP-DNA adduct formed is (+)-7 $\beta, 8 \alpha$-dihydroxy- $9 \alpha, 10 \alpha$-epoxy-7,8,9,10-tetrahydrobenzo[a]pyrene (BPDE) bound through a trans addition to the exocyclic amino group of deoxyguanosine (reviewed in [2]). Despite the knowledge of the metabolic reactions leading up to and including interaction of the electrophilic metabolites with DNA, the impact of individual DNA adducts derived from the in vivo metabolism of BP upon the tissue and species specificity of carcinogenesis remains uncertain. Elucidation of the structures of the adducts produced and the metabolic pathways leading to their formation should be useful in establishing these relationships. The present study examines the types and levels of DNA adducts produced concomitantly in liver, lung, kidney and spleen after the single i.p. injection of BP in rats. For detection of the adducts we used synchronous fluorescence spectrophotometry (s.f.s.) [3].

BP was purchased from Sigma Chemical Co. (St. Louis, MO, U.S.A.). BPDE used for DNA modification in vitro was kindly supplied by $\mathrm{Dr}$ K. Alexandrov (Villejuif, France). BP-tetrol standards: $7,10 / 8,9$ and $7 / 8,9,10$ tetrols were prepared by hydrolysis of BPDE in water $(\mathrm{pH}$ 7.0) and subsequently extracted with ethyl acetate [4]. Male Wistar rats weighing about $200 \mathrm{~g}$ were used. BP was administered as a uniform suspension in sunflower seed oil in a single i.p. injection at $0.05 \mathrm{ml} / 10 \mathrm{~g}$ body weight to yield a final dose of $100 \mathrm{mg} / \mathrm{kg}$. Three animals were used for each experimental group and control animals received i.p. injections of the oil carrier only. Rats were anaesthetised with ether at various times after BP administration and then killed by cervical dislocation. Livers, lungs, kidneys and spleens were surgically removed and frozen at $-20^{\circ} \mathrm{C}$. Microsomes for incubations of BPDE with NADPH were prepared from the livers of male Wistar rats pre-treated with 3-methylcholanthrene (MC) (i.p. twice in a dose of $25 \mathrm{mg} / \mathrm{kg}$ of body weight) by differential centrifugation [5]. DNA isolation and analysis of DNA adducts was carried out as previously described [6]. DNA samples (100 $200 \mu \mathrm{g} / \mathrm{ml}$ of $10 \mathrm{mM}$ Tris $/ 1 \mathrm{mM}$ EDTA buffer, $\mathrm{pH} 8.0$ ) were hydrolysed in $0.1 \mathrm{M} \mathrm{HCl}$ at $90^{\circ} \mathrm{C}$ for a period of $3 \mathrm{~h}$. The spectral properties of the hydrolysis products were examined without further purification using a Perkin-Elmer 650-10S fluorescence spectrophotometer.

Figure 1 presents the spectra generated by s.f.s. after acid hydrolysis of DNA samples and authentic standard materials. These spectra were determined by simultaneously driving

\footnotetext{
${ }^{1}$ Abbreviations: BP, benzo[a]pyrene; BPDE, (+)-7 $\beta, 8 \alpha$-dihydroxy- $9 \alpha, 10 \alpha$-epoxy-7,8,9,10-tetrahydrobenzo[a]pyrene; e.l.i.s.a., enzyme-linked immunosorbent assay; i.p., intraperitoneal; MC, 3-methylcholanthrene; s.f.s., synchronous fluorescence spectrophotometry
} 


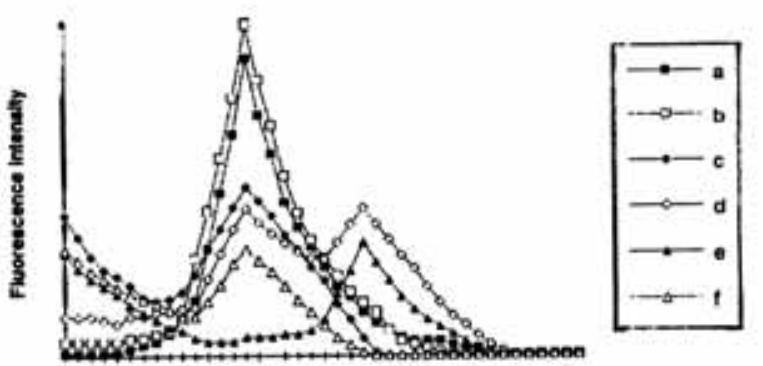

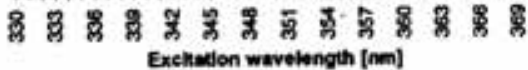

Fig. 1. Symchronous fluorescence spectra $(\Delta \lambda=34$ $n m$ ) of hydrolysis products of: $b, D N A$ modified with $B P D E$ in vitro; $c$, rat spleen DNA $72 h$ after $B P$ treatment; d, rat kidney DNA $72 \mathrm{~h}$ after BP treatment; $e$, rat liver DNA $72 h$ after BP treatment; $f$, rat lung DNA $72 \mathrm{~h}$ after BP treatment, in comparison with BP-tetrol standards (a)

the excitation and emission monochromators of the fluorimeter with a fixed wavelength difference $(34 \mathrm{~nm})$.

DNA samples of rat spleen and lung gave each a fluorescent peak at $344 \mathrm{~nm}$ of excitation identical to those of authentic BP-tetrol standards. However DNA samples from kidney gave an additional peak at $353 \mathrm{~nm}$ of excitation and in the DNA samples of the liver it was the only peak observed. Previously we have found a similar peak in the DNA samples from the mouse small intestine [6].

The nature of the product giving a peak in s.f.s. at $353 \mathrm{~nm}$ remains unknown, however several explanations of the origin of this product are possible. Some studies have demonstrated the formation of DNA ardducts derived from further oxidation of polycyclic aromatic hydrocarbon diol-epoxides [7,8]. In the case of $\mathrm{BP}$ the intermediate concerned is most likely 3,7,8-BP triol-epoxide which is formed after incubation of BPDE with either rat liver microsomes or nuclei [7]. Spectra of s.f.s. of calf thymus DNA modified in vitro in the presence of BPDE, NADPH and liver microsomes isolated from MC pre-treated rats or BPDE incubated with NADPH and liver microsomes isolated from MC pre-treated rats (Fig. 2) showed an additional peak but at $360 \mathrm{~nm}$ of excitation. Thus the possibility that an unknown product represents pentols released from BP triol-epoxide should be excluded.

Another possibility is that this adduct represents a modified form of BPDE-dGuo, possibly

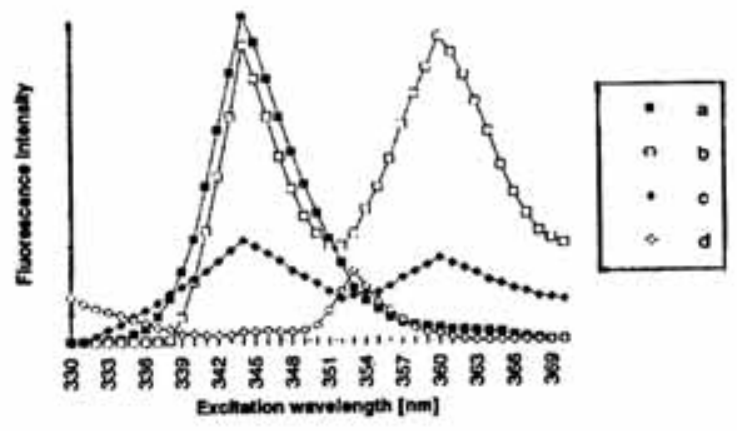

Fig. 2. Synchronous fluorescence spectra $(\Delta \lambda=34$ $\mathrm{nm}$ ) of hydrolysis products of rat liver DNA $72 \mathrm{~h}$ after BP i.p. treatment $(d)$ in comparison with products formed following: $a$, extraction of BPDE with acetone; $b$, microsomal incubation of BPDE with NADPH; $c$, microsomal incubation of BPDE with calf thymus DNA and NADPH

due to conjugation with glucuronide. In support of this hypothesis, we did not observe the additional peak in s.f.s. spectra of DNA modified upon in vitro reaction with BP or BPDE without addition of NADPH and microsomes (data not shown and Fig.1). Such possibility was also suggested by Ross et al. $[9,10]$ who analysed BP-DNA in different tissues of CD rats by the ${ }^{32} \mathrm{P}$-postlabeling technique and found a novel major adduct in the liver DNA. Consistent with further modification of the adduct was the observed increase in the ratio of novel adduct to BPDE-dGuo at increasing times after BP administration. On the other hand Boroujerdi et al. [11] demonstrated that, at very early times after intravenous administration of BP, the 9-hydroxy BP pathway predominates in rat liver and lung. Thus, more detailed studies which are in progress are needed to elucidate the nature of the unknown product observed in our s.f.s. spectra.

We have also found marked differences between rat tissues in the amount of BP-DNA adducts. Maximal levels of adducts occurred at about 3 days after BP administration (Table 1). The highest level of BPDE-DNA adducts (peak $344 \mathrm{~nm}$ ) expressed as pmol of tetrols released per mg DNA was found in kidney. In liver this adduct was not detectable and in spleen the level of BPDE-DNA adducts was slightly higher than in lung (Fig. 3). Our results indicate that there is no direct relationship between the level of BPDE-DNA adducts and induction of 


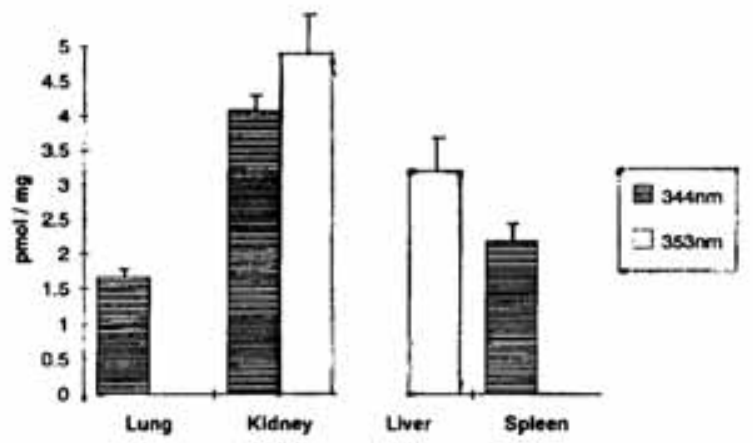

Fig. 3. The levels of BP-DNA adducts in rat lung, kidney, liver and spleen $72 \mathrm{~h}$ after i.p. BP treatment

the tumorogenesis process. Respiratory, gastric and mammary tissues have been identified as the primary targets for BP carcinogenesis in the rat [9]. Thus the relevant delivered dose of $\mathrm{BP}$ should be the dose bound to the DNA of these target tissues. However, several mechanisms could contribute to differences between tissues in DNA adducts levels. The tissues may exhibit quantitative differences in adduct formation and removal. Differences in individual tissue repair capabilities and cell division and turn-

Table 1

$B P-D N A$ adducts levels in rat liver, lung and spleen measured at different times after i.p. treatment

\begin{tabular}{|c|c|c|c|c|}
\hline \multirow{2}{*}{$\begin{array}{c}\text { Time } \\
\text { (days) }\end{array}$} & \multicolumn{2}{|c|}{$\begin{array}{c}\text { Peak } \\
(\mathrm{nm})\end{array}$} & \multicolumn{3}{|c|}{ Tissue (pmole/mg DNA) } \\
\hline \multirow{2}{*}{1} & 344 & n.d.* & Lung & Spleen \\
\cline { 2 - 5 } & 353 & n.d. & n.d. & n.d. \\
\hline \multirow{2}{*}{2} & 344 & n.d. & 0.42 & n.d. \\
\cline { 2 - 5 } & 353 & n.d. & n.d. & n.d. \\
\hline \multirow{2}{*}{3} & 344 & 0.33 & 1.00 & 1.75 \\
\cline { 2 - 5 } & 353 & 3.6 & n.d. & n.d. \\
\hline \multirow{2}{*}{4} & 344 & n.d. & 0.83 & 1.67 \\
\cline { 2 - 5 } & 353 & 3.0 & n.d. & n.d. \\
\hline \multirow{2}{*}{7} & 344 & n.d. & 1.08 & 2.08 \\
\cline { 2 - 5 } & 353 & 2.67 & n.d. & n.d. \\
\hline
\end{tabular}

*not detectable over rates may also influence lifetimes of the adducts.

In our studies we have used s.f.s. for adducts detection. This technique was applied for BPDE-DNA measurement of adducts formed in vivo by Bjelogrlic et al. [12]. Their results were comparable to the studies using e.l.i.s.a. immunoassay and showed that the s.f.s. method is useful in animal studies. However, the limitations of this method did not allow us to estimate the levels of individual BP-DNA adducts or to identify which residues in DNA were modified. More detailed studies are under way to establish whether the levels of individual adducts are critical in determination of the tissue specific susceptibility to BP carcinogenesis in the rat.

\section{REFERENCES}

1. Pelkonen, O. \& Nebert, D.W. (1982) Pharmacol. Rev. 34, 189 - 222.

2. Baer-Dubowska, W. (1992) Post. Hig. Med. Dośw. 46, 55 - 68 .

3. Vahakangas, K., Haugen, A. \& Harris, C.C. (1985) Carcinogenesis 6, 1109 - 1116.

4. Alexandrov, K. \& Rojas-Moreno, M. (1990) Arch. Geschwulstforch. 60, 329 - 340.

5. Gnojkowski, J., Baer-Dubowska, W., Klimek, D. \& Chmiel, J. (1984) Toxicology 32, 335 - 342.

6. Brauze, D., Mikstacka, R. \& Baer-Dubowska, W. (1991) Carcinogenesis 12, 1607 - 1611.

7. Dock, L., Waern, F., Martinez, M., Grover, P.L. \& Jernstom, B. (1986) Chem.-Biol. Interact. 58, 301 318.

8. Hall, M., Parker, D.K., Hewer, A.J., Phillips, H. \& Grover, P.L. (1988) Carcinogenesis 9, 865 - 868.

9. Ross, J., Nelson, G., Kligerman, A., Erexon, G., Bryant, M., Earley, M., Gupta, R.C. \& Nesnow, S. (1990) Cancer Res. 50, 5088 - 5094.

10. Ross, J., Nelson, G., Erexson, G., Kligerman, A., Earley, K., Gupta, R.C. \& Nesnow, S. (1991) Carcinogenesis 12, 1953 - 1955.

11. Boroujerdi, M., Kung, H., Wilson, A.G.E. \& Anderson, M.W. (1981) Cancer Res. 41, 951 - 957.

12. Bjelogrlic, N., Iscan, M., Raunio, H., Pelkonen, O. \& Vahakangas, K. (1989) Chem.-Biol. Interact. 70, $51-61$. 